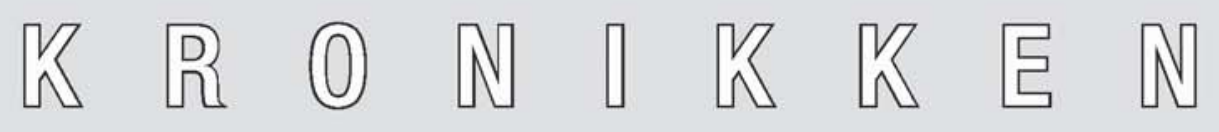

\title{
Er boligområderne i børnehøjde? \\ - om mobiliteter, forbindelser og (udendørs) liv
}

af Trine Fotel 
$\mathrm{B}$ ørn lever vidt forskellige hverdagsliv i dagens boligområder. Nogle lever alle døgnets 24 timer inden for boligområdets (u)formelle grænser; andre lever et hverdagsliv med en mængde fysiske og fx virtuelle og kommunikative mobiliteter, hvorigennem sociale relationer strækkes ud i et globalt rum. Et mobilitetssociologisk perspektiv kan belyse disse sammenhænge mellem "det sociale" og "det mobile". Men ligeledes præger boligområders konkrete udformning børns lyst til at bevæge sig og opholde sig udendørs. Med tanke for den vestlige befolknings tendens til overvægt, er denne sammenhæng ikke uden sundhedspolitisk relevans. Med afsæt i materiale fra 11-12-årige børn, argumenterer jeg for, at perspektivisme og forskning i ganske almindelige hverdagsliv udgør et værdifuldt forskningsmæssigt bidrag, der beriger den by- og boligpolitiske debat.

\section{Værdien af børns perspektiver - og af et børneperspektiv}

"Børn" er i stigende grad et politiseret emne. De har haft deres egne FN-baserede rettighedsanvisninger i snart to årtier (FNs Børnekonvention 1989), og nogle danske unge ønsker i dag valgretsalderen nedsat til 16 år. I 1953 var valgretsalderen så "høj" som 23 år og først i 1978 blev den 18 år, som vi kender den i dag. Det er et konkret eksempel på, hvordan alderstilknyttede rettigheder er socialt konstruerede, nøjagtig som en række andre medborgerskabsorienterede diskurser, rettigheder og pligter.

Kategorien "børn" bør sociologisk set anskues som udtryk for en socialt konstrueret og samfundsmæssigt struktureret gruppe. At børn selv aktivt fortolker og reproducerer deres position(er), er et vigtigt og konstruktivt opgør med tidligere udviklingspsykologiske opfattelser af børns faseopdelte og trinvise aldersbaserede udvikling (Corsaro 1998; James et al. 1998). Alligevel kræver et sociologisk perspektiv på børn som gruppe en mængde balanceakter, for at undgå en generaliseret fastlåsning af bestemte karakteristika til en given aldersgruppe. Kategorien "børn" inkluderer almindeligvis alle under 18 år, men denne samfundsmæssigt strukturerede gruppe er selvsagt også heterogen og fuld af individuelle kompetencer, konstruktioner osv.

At tillægge børns egne perspektiver, deres meninger holdninger og oplevelser vægt, ser jeg som en demokratisk værdi, der bør respekteres som del af den samfundsmæssige politiske dynamik. Konsekvensen er ikke, at børn altid skal høres og inddrages. Deres perspektiver er heller ikke mere uskyldige eller oprindelige end andres, og de skal ikke altid have ret. Men nogle gange bør tiden til at inddrage børn i forskellige aldre prioriteres. Ofte skal der lidt mere metodisk kreativitet og et par etiske overvejelser til. Netop i forhold til hverdagslivet i dagens boligområder, ligger der en oplagt mulighed for at afsøge børns holdninger.

Når jeg i det følgende skitserer resultaterne af en forskningsproces, hvor børn i betragteligt omfang leverede materialet, så er det vigtigt at være opmærksom på de perspektiver, der konstrueres undervejs. Jeg formidler ofte ét 
børneperspektiv, som dog dækker over utallige unikke og også generationsstrukturerede, børneperspektiver. Ligeledes inkluderer min konstruktion af ét børneperspektiv uundgåeligt mit eget positionelle perspektiv. Beslægtede processer er et grundvilkår i megen socialkonstruktivistisk forskning, men ikke desto mindre stadig vigtige.

\section{By, børn og boliger}

Den franske filosof og sociolog Henri Lefebvre har i sine mange skrifter om by, hverdagsliv og en humanistisk orienteret marxismefortolkning gang på gang diskuteret "retten til byen" og mere generelt "retten til produktionen af rum". Tid og rum er i Lefebvres teori en ontologisk medproduceret dimension, som for eksempel finder sted i hverdagslivets mobile praksisser. De mobilitetsmuligheder, som for eksempel børn tilbydes, er præget af blandt andet forældres af og til omfattende formaninger (Fotel \& Thomsen 2004), men også af de rationaler som ligger i blandt andet byplanlægningen. Hos Lefebvre får vi en gennemgående politisk opfordring til at basere rummets produktion på en heterogenitet og en fleksibilitet, der med perspektiver fra "det levede rum", skaber en demokratisk modificering af "kapitalistisk" prægede byer (Lefebvre fx 1996; 1991).

At integrere børns perspektiver i bypolitik og byplanlægning kan være én måde at skabe en demokratisk og levet by. Forskning i børns perspektiver finder sted i en mængde samfundsvidenskabelige miljøer, men der har været en tendens til at fokusere på relativt lukkede og definerede rum, såsom $\mathrm{fx}$ børnehaven, legepladsen eller skolen ( $\mathrm{fx}$ Schytte 2006; Gitz-Johansen T. et al., 2001). Disse afgrænsede rum er vigtige i børns institutionaliserede hverdagsliv, men vi må styrke det forskningsmæssige perspektiv, der indfanger ruterne, bevægelserne og oplevelserne i byens rum generelt. Her findes vigtige pointer i forhold til forståelsen af børn som aktører og demokratiske medborgere i det offentlige rum (Carstensen 2005; Rasmussen2004; Holloway \& Valentine 2000).

Udgørende en femtedel af den danske befolkning, bor 65 pct. af de danske børn således i enfamiliehuse, 22 pct. i etageboliger og 12 pct. i række-, kædeeller dobbelthuse (Danmarks Statistik, 2005). Plads i og rundt om boligen, naboskabet, familiens socio-økonomiske og kulturelle forhold samt lokalområdets fritidsudbud er vigtige aspekter, der præger et børneliv. Med en række geografiske forskelle har langt de fleste børnefamilier en eller flere biler. Bilejerskabet betyder en hel del for karakteren af de strømme og rytmer, der præger børns hverdagsliv.

Med en bil (og voksne med tid til at køre barnet i den) åbnes op for, at fritidsaktiviteter og kammeratskabskredsen kan konstrueres uden at tage nævneværdigt hensyn til de fysiske afstande. Nogle gange er bilen det eneste, men også det kvalitativt bedste sted, hvor familiemedlemmerne er samlet $\mathrm{i}$ løbet af en dag fuld af individuelle aktiviteter. 20 pct. af dagens børnefamilier 
har ikke bil. Selvom de af og til kan låne en, så er børnene uden daglig bilrådighed ofte i en helt anden grad henvist til det nære boligområdes faciliteter. Om der ligger fx en sportshal tæt på, og om det er muligt for barnet at færdes alene på cykel og gåben, får pludselig afgørende betydning.

Tre-fjerdedele af de knap fyrre 11-12-årige børn, som jeg var i kontakt med i løbet af forår og sommer 2003, havde bil i familien. Jeg talte med bredt med børnene om deres hverdagsliv, samt deres oplevelser og erfaringer med transport og bevægelse. Børnene boede i to forskellige boligområder med forskellig fysisk og socioøkonomisk profil; fx var boligområdet i det centrale bykvarter præget af en hel del gennemkørende trafik, mens det forstadsprægede boligområde var præget af trafikseparation og et omfattende cykelstinet. Alle børn tegnede en mængde tegninger, skrev dagbøger og tog billeder med engangskameraer. Materialet diskuterede jeg med børnene både kollektivt, i mindre grupper og individuelt. Ligeledes svarede både børn og forældre på et mindre spørgeskema, og knap 15 forældre blev interviewet. Alt $i$ alt fremkom et materiale, som var rigt og multipelt, men som også indeholdte mønstre og tydelige "mobilitetspositioner".

\section{Forskellig færden i to boligområder}

Noget af det som overraskede mig mest, var børnenes uopfordrede glæde ved at færdes udendørs. Selvom de også sad inde "foran computeren", så afspejlede dagbøger, tegninger og interviews, at det at være udendørs til formelle og uformelle aktiviteter er generelt værdsat. Børnenes konkrete praksis var dog vidt forskellig i de to boligområder. I byområdet gik de fleste børn, men de ønskede brændende at have bedre mulighed for at benytte de hurtige "mobilitetsteknologier", som fx cykler og løbehjul. I det forstadsprægede boligområde var det at "hænge ud" på stierne og det at være i fart på fx cykel en udbredt og attraktiv praksis for de fleste børn. Alt i alt peger materialet på, at det at være selvstændigt mobil og det at kunne "hænge ud" uden voksenopsyn er generelt attraktivt for både drenge og piger.

Måske tilbyder dagens boligområder ikke nok af sådanne steder? Netop i 11-12 års alderen oplever børnene, at de er for store til at lege på legepladserne, og omvendt er de ofte lidt for unge til at benytte byernes butikker og cafeer fuldt ud. Stier, semi-offentlige mødesteder o. lign. i nabolaget kan få karakter af "liminale rum", hvor børnene mødes på tværs af aldre, køn og etniciteter (Matthews 2003). Et mere overordnet spørgsmål, som sætter situationen lidt på spidsen, er dog, om vi overhovedet ønsker, at børn skal færdes mere i det offentlige rum? I den anglo-saksiske kontekst synes diskursen om "stranger-danger" for eksempel så stærk, at børn der færdes alene eller i grupper, ofte betragtes som enten stakkels og "forsømte", eller som et decideret truende indslag (Valentine 2004).

I mit materiale var det at have forbindelser til fritidsaktiviteter og til kammerater inden for en overkommelig afstand ligeledes tydelig værdsat. Vigtig- 
heden af selv at kunne færdes på uformel vis, afspejlede sig i både børns tegninger, interviews og dagbøger. I betragtning af hvor stor en del af børnenes liv der generelt er skemalagt med skole, diverse fritidsordninger og en mængde formelle fritidsaktiviteter, er det egentlig ikke et overraskende ønske. Men i lyset af, at en af de helt store politiske opgaver er at håndtere sundhedsforebyggelsen og fx kroniske sygdomme som følge af overvægt, da er det måske et ønske som er værd at imødekomme? Forskning viser, at hvis hverdagens rutineprægede aktiviteter, herunder skole og indkøb, foretages aktivt (på cykel, i gang o. lign.), da er også resten af dagen langt mere aktiv. Ved at udstyre børn med en GPS kan sådanne forskelle i kalorieforbrug dokumenteres, og ydermere pege på en tendens til, at børn bruger flere kalorier i uformelle fx boldspilsaktiviteter end i formelt organiserede (Mackett 2007). Som altid er det nemmere at rejse debatten end at løse problemet, men jeg tror, at der i netværk mellem fx skoler, forældre og en fleksibelt indstillet kommune, vil kunne findes lokale løsninger, der på forskellig vis kan fremme den uformelle hverdagsmobilitet i boligområderne.

\section{Fremtidsstrømme og -drømme}

$\mathrm{Nu}$ er der jo en hel del mobilitet allerede. Teoretisk konstitueres det sociale i stigende grad mobilt og det urbane kan anskues som mobile fortætninger (Urry 2000; Amin \& Thrift 2002). Jeg vil dog godt have en tydeligere debat om mobiliteternes forskellige temporaliteter, socialiteter og perspektiver. Én ting er at vi i stigende grad har "civil societies of automobility" (Urry 2000); bilerne fylder ganske enkelt mere i det offentlige rum, og samtaler, politisk debat og social aktivitet rykkes ofte enten ind i bilerne eller koncentreres på steder, der bedst kan nås via bilen.

Noget ganske andet er at afsøge, hvordan det sociale og det mobile på forskellig vis præger menneskers hverdagsliv og livet i for eksempel boligområder. Tendensen peger i øjeblikket $i$ retning af, at lokale skoler og institutioner lukkes og fritidsaktiviteter koncentreres. Det betyder, at børn uden bilrådighed og en velvillig voksen til at køre dem rundt, bliver en stadig mere "stedsbunden" gruppe. Pointen er, at denne tendens ikke kun rammer de økonomisk svage børn, men også de børn hvis forældre ikke har tid til at agere chauffører. Det at have "den gode hverdagsmobilitet" er derfor meget andet og mere, end hvad der kan indfanges af fx Bourdieus traditionelle kapitalbegreber. Derfor har jeg også andetsteds skitseret, hvordan et begreb om mobilitetskapital, kan være med til at indfange sådanne tids-rumlige ressource- og positioneringsdimensioner (Fotel 2007).

Når jeg på forskellig vis talte med børnene om, hvordan de ser deres fremtidige hverdagsliv, da er bilen for de fleste et must. Den er samtidig et stykke omsorgsteknologi, som skal anvendes aktivt: som forældre vil de gerne køre egne børn, "for så bliver det gladere". Bilen er det hurtigste transportmiddel især til og fra arbejde; den er "hyggelig", "rar" og "afslappende", og det er 
sjovt at køre som "de tyske motorvejs-agtigt" (Fotel 2007). Alle disse udsagn er interessante, men de udtrykker samtidig en ikke overraskende reproduktion af generelle samfundsmæssige diskurser. Det er mere overraskende, at materialet ikke pegede på nævneværdige kønsforskelle, og at en hel del børn fra begge boligområder, ønskede at bibeholde muligheden for at cykle til en lang række dagligdags gøremål.

\section{En demokratisk dynamik}

Jeg er overrasket over, at de seneste 10 års politiske satsninger på helhedsorienteret og borgerinddragende områdefornyelse, byfornyelse, kvarterløft osv., ikke har haft et tydeligt fokus på at inddrage både større og større børn. Kunne nationale politiske satsninger ikke netop være stedet at "gå foran?"

Som følge af Børnerådets opfølgning på FNs børnekonvention, er de danske kommuner forpligtiget til at udarbejde en børnepolitik. En del kommuner har gjort det, men ofte forbigås hele den by- og boligpolitiske palet. Dette skyldes måske, at denne rækker ind over det traditionelt mere træge område for "fysisk planlægning" (Børnerådet 2001; Carstensen et al. 2004). Ofte kræver inddragelse af børn mere tid og lidt metodisk kreativitet, og byer og boligområder vil ikke blive omkalfatret på én nat. Men der ligger et demokratisk og uudnyttet potentiale $i$ at inddrage børn i større eller mindre omfang, alt efter den enkelte kontekst.

At anvende børns holdninger, oplevelser og erfaringer i sammenspil med andre aktører, kan være et smukt eksempel på en Lefebvre-inspireret demokratisk produktion af rum. Den vægt, deres perspektiver så skal have, må bero på en deliberativ dialog. Da jeg i et spørgeskema spurgte børnene "hvis du var borgmester, hvad ville du så bestemme?", da var langt de fleste svar rettet mod "bedre fortove" og "flere cykelstier" samt "færre biler". Disse ønsker afspejler meget fint forbedringer i forhold til børnenes egen mobilitet, men samtidig kan ønskerne være svære at efterkomme i større stil. Alligevel kan der være andre situationer, projekter og netværk mellem fx skoler, forældre og kommuner, hvor børneperspektivet kan tillægges mere vægt.

Børns rumlige praksis - fx "huler i krattet" eller "hængen ud" - sætter sig sjældent af sig selv varige spor det offentlige rum. Men lad os satse på en politisk årvågenhed over for den betydning boligområder har, ikke mindst for de knapt så mobile aktører. Og lad os ikke mindst styrke den samfundsvidenskabelige forskning i de institutionelle processer, der er med til at styrke en inkluderende og demokratisk produktion af byens rum!

Trine Fotel

E-mail: trinen@ruc.dk 


\section{Litteratur}

Amin, A. \& Thrift, N. 2002: Cities: Re-imagining the urban. Cambridge: Polity.

Børnerådet, Danmark. http://www.boerneraadet.dk/fn's++børnekonvention Accessed 3 oktober 2007.

Børnerådet 2000: Et skridt på vej-Om FN's Børnekonvention i kommunerne. København: Børnerådet.

Carstensen, T. A. 2005: Kvarteret $i$ børnehøjde, om steder og strækninger $i$ moderne børns hverdagsliv. PhD Arkitektskolen i Aarhus. Skov \& Landskab. KVL: Frederiksberg.

Carstensen, T. A. et al. 2004: Giv børnene en stemme i byplanlægningen - hvorfor, hvornår, hvordan? Hæfte. Skov \& Landskab. Frederiksberg: KVL

Corsaro, W. 1997: The sociology of childhood. Thousand Oaks, Californien: Pine Forge Press.

Danmarks Statistik 2005: Børns levevilkår. København: Danmark Statistik FNs Børnekonvention af 1989.

Fotel, T. 2007: Mobilitet $i$ børnehøjde. En mobilitetssociologisk analyse af praksis, velfærd og ulighed $i$ børns hverdagsliv. Roskilde Universitetscenter. PhD Afhandling.

Fotel, T. \& Thomsen, T. U. 2004: "The surveillance of Children's Mobility", Surveillance $\mathcal{E}$ Society 1 (4):535-554.

Gitz-Johansen, T. et al. 2001: Samspil mellem børn og skolens fysiske ramme København: Rum Form Funktion.

Holloway, S. \& Valentine, G. 2000: Children's geographies: playing, living, learning. New York: Routledge.

James J. et al. 1998: Theorizing Childhood. Cambridge: Polity.

Rasmussen, K. 2004: Børnene i kvarteret, kvarteret i børnene: om børns hverdagsliv, steder og ruter. Frederiksberg: Roskilde Universitetsforlag.

Lefebvre, H. 1996: "Right to the City" in H. Lefebvre: Writings on Cities pp. 63-181. Malden: Blackwell.

Lefebvre 1991 [1974]: The production of space. Oxford: Blackwell

Mackett, R. 2007: Children's physical activity: the links with car use and the local environment. Paper presented at workshop on "Physical activity and car dependency in modern childhood", 11 September. Oslo: TØI.

Matthews, H. 2003: "The street as a liminal space: the barbed spaces of childhood" in Christensen \& O'Brien (eds): Children in the City. London and New York: Routledge Falmers.

Schytte, B. 2006: Inddragelse af børn og unge $i$ udvikling af udemiljøer: erfaringer fra et projekt $i$ Vollsmose. Park- og Vejafdelingen: Odense Kommune.

Urry 2000: Sociology beyond society: mobilities for the twenty-first century. London: Routledge.

Valentine, G. 2005: Public Space and the culture of Childhood. Aldershot: Ashgate. 